Jurnal Ilmiah

ILMU KOMPUTER

Universitas Udayana

Vol. XI, No. 1, April 2018

ISSN 1979 - 5661

\title{
MODELING CARGO DALAM PEMILIHAN AIRLINE
}

\author{
Ni Made Kariati ${ }^{1}$, Putu Adi Suprapto ${ }^{2}$, Lily Marheni ${ }^{3}$ \\ ${ }^{1,3}$ Jurusan Administrasi Niaga \\ ${ }^{2}$ jurusan Akuntansi \\ Politeknik Negeri Bali
}

\begin{abstract}
ABSTRAK
Mengeliatnya bisnis E-Commerce, memberikan harapan besar pada pertumubuhan bisnis cargo di Indonesia. Bisnis cargo merupakan salah satu penyokong sarana prasarana pariwisata di Bali. Perdagangan awalnya hanya dilakukan di satu negara, tetapi selama bertahun-tahun perdagangan telah berkembang tersebut dan dilakukan antar negara. Hal ini karena setiap negara memiliki iklim yang berbeda, sumber daya alam, karakteristik, geografis demografis struktur,, ekonomi, dan struktur sosial. Barang Efek dari satu tempat ke tempat lain akan membutuhkan armada transportasi, baik udara, darat, atau laut. Saat sekarang hari, eksportir dan importir lebih cenderung menggunakan angkutan udara karena kelebihannya apakah itu efisien dalam waktu tetapi juga mampu menjangkau semua kota di dunia. Pertumbuhan yang cepat, bisnis eksporimpor memicu pertumbuhan perusahaan logistik lokal, salah satunya adalah PT Fajar Insan Nusantara Logistics Bali (FIN Logistics Bali)., FIN Logistics Bali adalah perusahaan jasa pengiriman untuk pengiriman layanan domestik dan internasional barang darat, laut, dan udara. Namun proses memilih penerbangan oleh pelanggan di perusahaan masih dilakukan secara intuisi dan berorientasi pada harga murah.. Dalam penelitian ini dilakukan modeling kasus pemilihan iarline dengan mempertimbangkan kepentingan, harga, keselamatan, kecepatan. Hasil akhir dari model perhitungan untuk setiap alternatif akan peringkat semua alternatif berdasarkan skor tertinggi, yang akan digunakan sebagai pertimbangan atau rekomendasi kepada pelanggan dalam memilih maskapai, tapi keputusan tetap di tangan pelanggan.
\end{abstract}

Kata kunci : Cargo, DSS, Airline, Alternatif, Kreteria, Keputusan

\begin{abstract}
In the beginning trading is only done in one country, but over years trading has develoved and is done between countries. It is because each country has different climate, natural resources, characteristics, geographic, demographic, economic structure and social structure. Goods Exchange from one place to another would require a fleet of transportation, whether by air, land, or sea. Currently now a days, exporters and importers are more likely to use air transportion because of its advantages whether it is efficient in time but also able to reach all cities in the world. Rapid growth, of import-export business triggers the growth of the local logistics companies, one of which is PT Fajar Insan Nusantara Logistics Bali, it is a delivery service company for domestic and international service delivery of goods by land, sea, and air. However the process of selecting the airlines by the customer in the company is still based on their instincts and low prices. The final result of the calculation models for each alternative will rank all the alternatives based on the highest score, which will be used as consideration or
\end{abstract}


recommendation to customers in the selecting of airlines, but the decision remains in the hands of the customer, because research on the subject DSS (Decision Support System) only up to the recommendation.

\section{Keywords: Cargo, DSS, Airline, Alternatif, Creteria, Decision}

\section{PENDAHULUAN}

Mengeliatnya bisnis E-Commerce, memberikan harapan besar pada pertumubuhan bisnis cargo di Indonesia. Bisnis cargo merupakan salah satu penyokong sarana prasarana pariwisata di Bali. Hubungan perdagangan pada awalnya hanya terbatas pada satu wilayah negara yang tertentu, tetapi dengan semakin berkembangnya arus perdagangan maka hubungan dagang tersebut tidak hanya dilakukan antar pengusaha dalam satu wilayah negara saja, tetapi juga dengan para pedagang dari negara lain, tidak terkecuali Indonesia. Mekanisme pertukaran barang dan jasa dilakukan dalam transakasi perdagangan internasional yang lebih dikenal dengan istilah ekspor impor. Proses ekspor pada umumnya adalah tindakan untuk mengeluarkan barang atau komoditas dari dalam negeri untuk memasukannya ke negara lain. Impor adalah proses transportasi barang atau komoditas dari suatu negara ke negara lain secara legal, umumnya dalam proses perdagangan, dan pada hakikatnya adalah suatu transaksi sederhana yang tidak lebih dari membeli dan menjual barang antara pengusaha-pengusaha yang bertempat tinggal atau berdomisili dinegara-negara yang berbeda.

Usaha untuk membantu dan mempermudah customer memilih airlines sesuai kebutuhan customer tentang pemilihan airlines menjadi permasalahan yang serius untuk ke depan, maka diperlukan suatu sistem yang dapat mengolah data untuk mendukung keputusan dalam pemilihan airlines yang tepat. Mengingat banyaknya customer yang belum mengetahui informasi dan cara memilih airlines dan sering kali customer memilih airlines hanya dengan insting atau mengikuti saja arah di cargo, sedangkan dalam suatu permainan bisnis pengambilan sebuah keputusan harus didasari atas data dan informasi,untuk mendapatkan keuntungan maximal. Kecenderungan menggunakan transfortasi udara karena jasa angkutan udara walaupun porsinya tidak sebesar jasa angkutan laut, namun kehadirannya sangat dibutuhkan para pelaku perdagangan. Kelebihan utama jasa angkutan udara dibanding jasa angkutan lainnya adalah dalam hal efisiensi waktu. Garuda Indonesia optimis bisnis kargo perusahaan akan tumbuh tahun depan sejalan dengan pertumbuhan e-commerce. Perusahaan pelat merah ini menargetkan pendapatan bisnis cargo bisa mencapai US\$ 300 juta di 2017, naik dari perkiraan US\$220 juta sepanjang tahun ini, dikutip dari laman https://industri.kontan.co.id/news/prospekbisnis-kargo-masih-cerah-di-2017.

Berdasarkan latar belakang tersebut maka penelitian ini difokuskan terhadap bagaimana merancang Model Decision support system untuk menentukan airlines yang akan digunakan sesuai prioritas kebutuhan customer dan merumuskan model tersebut kedalam suatu pernyataan. Permasalahan ini mencakup penentuan kriteria dan alternatif yang terlibat dalam suatu pemilihan airlines oleh customer.

\section{MATERI DAN METODE}

\section{Materi}

\section{a) Lokasi Penelitian}

Penelitian ini berlokasi di PT Fajar Insan Nusantara (FIN Logistic) yang 
berada di Jl. Bypass Ngurah Rai No. 11 Kuta Denpasar, Bali - Indonesia.

\section{b) Obyek penelitian}

Obyek penelitian untuk skripsi ini adalah sistem pendukung keputusan untuk penentuan airlines di FIN Logistic Bali.

c) Formulasi keilmuan dan

\section{Identifikasi variabel}

c.1. Kriteria

c.2. Modeling Profil Matching

\section{d) Tahapan pengumpulan data}

Pengumpulan data dilakukan dnegan teknik, Studi Literatur penulis melakukan kegiatan pengumpulan data dengan membaca buku pedoman tentang perusahaan serta mencari informasi melalui internet dan membaca profil perusahaan yang berkaitan dengan perusahaan. Pengamatan (Observasi),penulis melakukan pengamtan (observasi) ke perusahaan logistik untuk mengumpulkan data dan informasi mengenai persyaratan pengiriman, daftar airlines, daftar harga dll.

\section{Metode}

\section{a. Metode Pengembangan Sistem}

Metode merupakan cara atau jalan yang ditempuh untuk mencapai tujuan.
Metode dalam pengembangan sistem modelling pemilihan airline ini mengunakan SDLC (system developmen ${ }^{t}$ life cycle). Metode ini yang akan digunakan pada perancangan system pendukung keputusan yaitu menerapkan siklus hidup pengembangan system. Metode SDLC menggunakan pendekatan sistem yang disebut pendekatan air terjun (waterfall approach), yang menggunakan beberapa tahapan dalam pengembangan sistem yaitu model yang bersifat sistematis dan berurut menurun.

\section{b. Metode Pengolahan Data}

Pada tahap ini data yang diperoleh akan diolah dengan menggunakan rumusan profil matching.

Langkah-langkah Penyelesaian dengan Profil Matching :

1. Perhitungan Pemetaan GAP

2. Menentukan Bobot

3. Perhitungan dan pengelompokkan Core dan Secondary Faktor

4. Perhitungan Nilai Total

5. Perhitungan Penentuan Hasil Akhir atau Ranking

Tabel 1. Bobot Gap

\begin{tabular}{|c|c|l|}
\hline Selisih & $\begin{array}{c}\text { Bobot } \\
\text { Nilai }\end{array}$ & \multicolumn{1}{|c|}{ Keterangan } \\
\hline 0 & 5 & Tidak ada selisih (kompetensi objek sesuai dg yg dibutuhkan) \\
\hline 1 & 4,5 & Kompetensi objek kelebihan 1 tingkat \\
\hline-1 & 4 & Kompetensi objek kekurangan 1 tingkat \\
\hline 2 & 3,5 & Kompetensi objek kelebihan 2 tingkat \\
\hline-2 & 3 & Kompetensi objek kekurangan 2 tingkat \\
\hline 3 & 2,5 & Kompetensi objek kelebihan 3 tingkat \\
\hline-3 & 2 & Kompetensi objek kekurangan 3 tingkat \\
\hline 4 & 1,5 & Kompetensi objek kelebihan 4 tingkat \\
\hline-4 & 1 & Kompetensi objek kekurangan 4 tingkat \\
\hline
\end{tabular}

\section{HASIL}

Kegiatan yang dilakukan dalam penelitian ini meliputi pengumpulan data dan informasi, pengolahan data sampai dengan perancangan model modelling suatu sistem yang dapat mengolah data untuk mendukung pengambilan keputusan dalam 
pemilihan airlines yang tepat. Kurun waktu yang sudah berjalan customer memilih airlines dalam kegiatan ekpor impor secara manual atau konvensional, customer harus datang langsung pada perusahaan untuk memperoleh informasi tentang airlinesairlines yang bermitra dengan perusahaan tersebut, hal ini tentu tidak efisien karena memerlukan waktu ekstra dalam memperoleh informasi dan memilih airlines, selain itu tidak adanya prosedur yang tetap sehingga seringkali costumer dalam pemilihan airlines hanya berdasarkan insting dan harga airlines yang murah, untuk itu diperlukan sebuah pemodelan sistem yang dapat membantu customer dalam memilih airlines. Sistem ini, dirancang untuk membantu dan memudahkan customer dalam memilih airlines yang dapat dijadikan bahan pertimbangan agar sesuai dengan kebutuhan customer dan sesuai dengan persyaratan pengiriman.

Proses selanjutnya, penulis melaksanakan observasi atau pengamatan, pada proses pengamatan penulis mendatangi langsung PT. Fajar Insan Nusantara (FIN) Logistik untuk mencari informasi tentang persyaratan pengiriman barang, daftar harga airlines, serta dokumen untuk pengiriman barang, berikutnya penulis melanjutkan pencarian data melalui studi lapangan, pada proses studi lapangan penulis menemukan beberapa informasi yang dapat dijadikan pertimbangan diluar dari persyaratan pengiriman misalnya ada beberapa airlines yang sering mengalami keterlambatan (delay) yang dapat merugikan customer, terdapat beberapa jenis airlines yang dalam proses pengiriman memerlukan data yang relatif rumit sehingga memerlukan waktu ekstra dalam mempersiapkan kelengkapan dokumen.

Pada tahap selanjutnya data yang diperoleh akan diolah dengan menggunakan rumusan profil matching. Sebelum data tersebut diolah menggunakan rumusan profil matching, tahapan yang dilakukan terlebih dahulu adalah menentukan atau mengklasifikasikan data tersebut meliputi kriteria, sub kriteria, serta alternatifalternatif pilihan. Metode profile matching atau pencocokan profil adalah metode yang sering sebagai mekanisme dalam pengambilan keputusan dengan mengasumsikan bahwa terdapat tingkat variabel prediktor yang ideal yang harus dipenuhi oleh subyek yang diteliti, bukannya tingkat minimal yang harus dipenuhi atau dilewati (Kusrini, 2007). Dalam proses Metode Profile matching secara garis besar merupakan proses membandingkan antara nilai data aktual dari suatu profil yang akan dinilai dengan nilai profil yang diharapkan, sehingga dapat diketahui perbedaan kompetensinya (disebut juga gap)

Tabel 2. Keterangan Sub Aspek Kriteria

\begin{tabular}{|l|l|}
\hline \multicolumn{1}{|c|}{ Kriteria } & \multicolumn{1}{c|}{ Keterangan Sub Kriteria } \\
\hline \multirow{4}{*}{ Aspek Harga } & Biaya \\
\cline { 2 - 2 } & Kecepatan \\
\cline { 2 - 2 } & Citra \\
\cline { 2 - 2 } Aspek Waktu & Volume \\
\cline { 2 - 2 } & Ketepatan Pengiriman \\
\cline { 2 - 2 } & Kecepatan Packaging \\
\cline { 2 - 2 } & Proses penyiapan pengiriman \\
\cline { 2 - 2 } Aspek Kenyamanan & Rroses bongkar muatan \\
\cline { 2 - 2 } & Kepengurusan dokumen \\
\cline { 2 - 2 } & Keramahan pelayanan \\
\hline
\end{tabular}




\begin{tabular}{|l|l|}
\hline \multirow{3}{*}{ Aspek Keamanan } & Keutuhan barang \\
\cline { 2 - 2 } & Asuransi (kehilangan, kerusakan, tertukar) \\
\cline { 2 - 2 } & Keadaan fisik barang \\
\hline
\end{tabular}

Proses pengolahan data akan masing - masing sub kriteria sebagai dilakukan dengan memberikan penilaian di berikut

Tabel 3. Alternatif Pesawat (Airlines)

\begin{tabular}{|c|l|}
\hline CODE & \multicolumn{1}{|c|}{ AIRLINES } \\
\hline C1 & Korean Airlines \\
\hline C2 & Garuda Indonesia \\
\hline C3 & Emirates Airlines \\
\hline C4 & Thai Airlines \\
\hline C5 & Cathay Airlines \\
\hline
\end{tabular}

Kerangka Penelitian

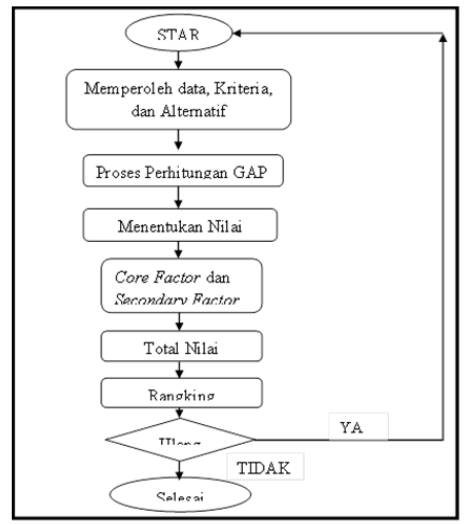

Gambar 1. Rancangan Penelitian

\section{PEMBAHASAN}

Dalam kasus ini penulis menggunakan perhitungan pemetaan gap indicator, yang dimaksud dengan gap di sini adalah selisih atau beda antara profil airlines sempurna dengan profil airlines dapat ditunjukkan pada rumus di bawah ini:

Gap = Profil airlines - profil airlines sempurna

Tabel 4. Perhitungan Gap Untuk Aspek Harga

\begin{tabular}{|c|c|c|c|c|c|c|c|}
\hline No & Id_Pesawat & 1 & 2 & 3 & 4 & 5 & \\
\hline 1 & C1 & 3 & 4 & 5 & 4 & 4 & \\
\hline 2 & C2 & 3 & 3 & 3 & 2 & 3 & \\
\hline 3 & C3 & 3 & 3 & 3 & 3 & 3 & \\
\hline 4 & C4 & 3 & 2 & 4 & 3 & 3 & \\
\hline 5 & C5 & 3 & 3 & 4 & 3 & 4 & \\
\hline \multicolumn{2}{|c|}{ Profil Airlines Sempurna } & 4 & 4 & 4 & 4 & 3 & \\
\hline 1 & C1 & -1 & 0 & 1 & 0 & 1 & \\
\hline 2 & C2 & -1 & -1 & -1 & -2 & 0 & \multirow{2}{*}{ Gap } \\
\hline 3 & C3 & -1 & -1 & -1 & -1 & 0 & \\
\hline 4 & C4 & -1 & -2 & 0 & -1 & 0 & \\
\hline 5 & C5 & -1 & -1 & 0 & -1 & 1 & \\
\hline
\end{tabular}


Keterangan : 1= Biaya, 2= Kecepatan, $3=$ Citra, $4=$ Volume, $5=$ Jarak

Terlihat pada Tabel 4 bahwa profil airlines sempurna untuk setiap faktor penilaian yang tertera dalam table tersebut adalah sebagai berikut : $(1)=4,(2)=4,(3)$ $=4,(4)=4,(5)=3$
Sebagai contoh, diambil airlines dengan code $\mathrm{C} 1$ dimana profilnya adalah (1) $=3,(2)=4,(3)=5,(4)=4,(5)=4$

Dengan demikian, hasil gap yang terjadi untuk setiap subaspeknya adalah (1) $=-1,(2)=0,(3)=1,(4)=0,(5)=1$

Tabel 5. Perhitungan Gap Untuk Aspek Waktu

\begin{tabular}{|c|c|c|c|c|c|c|}
\hline No & Id_Pesawat & 1 & 2 & 3 & 4 & \\
\hline 1 & C1 & 5 & 4 & 4 & 4 & \\
\hline 2 & C2 & 4 & 3 & 3 & 3 & \\
\hline 3 & C3 & 3 & 3 & 2 & 3 & \\
\hline 4 & C4 & 3 & 3 & 3 & 3 & \\
\hline 5 & C5 & 4 & 3 & 4 & 4 & \\
\hline \multicolumn{2}{|c|}{ Profil Airlines Sempurna } & 4 & 4 & 4 & 3 & \\
\hline 1 & C1 & 1 & 0 & 0 & 1 & \\
\hline 2 & C2 & 0 & -1 & -1 & 0 & \multirow{2}{*}{ Gap } \\
\hline 3 & C3 & -1 & -1 & -2 & 0 & \\
\hline 4 & C4 & -1 & -1 & -1 & 0 & \\
\hline 5 & C5 & 0 & -1 & 0 & 1 & \\
\hline
\end{tabular}

Keterangan 1: Ketepatan pengiriman, 2: Kecepatan packaging, 3: Proses penyiapan pengiriman,4: Proses bongkar muatan

Tabel 6. Perhitungan Gap Untuk Aspek Kenyaman

\begin{tabular}{|c|c|c|c|c|c|}
\hline No & Id_Pesawat & 1 & 2 & 3 & \\
\hline 1 & C1 & 5 & 5 & 5 & \\
\hline 2 & C2 & 4 & 4 & 4 & \\
\hline 3 & C3 & 2 & 3 & 3 \\
\hline 4 & C4 & 4 & 4 & 4 & \\
\hline 5 & C5 & 4 & 4 & 4 & \\
\hline \multicolumn{2}{|c|}{ Profil Airlines Sempurna } & 4 & 3 & 3 & \\
\hline 1 & C1 & 2 & 2 & 2 & \multirow{2}{*}{ Gap } \\
\hline 2 & C2 & -2 & 0 & 0 & \\
\hline 3 & C3 & 0 & 1 & 1 & \\
\hline 4 & C4 & 0 & 1 & 1 & \\
\hline 5 & C5 & &
\end{tabular}

Keterangan :1: Kepengurusan dokumen, 2: Keramahan pelayanan, 3: Kecepatan pelayanan

Tabel 7. Perhitungan Gap Untuk Aspek Keamanan

\begin{tabular}{|c|c|c|c|c|c|}
\hline No & Id_Pesawat & 1 & 2 & 3 & \\
\hline 1 & $\mathrm{C} 1$ & 5 & 5 & 5 & \\
\hline 2 & $\mathrm{C} 2$ & 4 & 4 & 4 & \\
\hline 3 & $\mathrm{C} 3$ & 4 & 4 & 4 & \\
\hline 4 & $\mathrm{C} 4$ & 5 & 4 & 3 & \\
\hline 5 & $\mathrm{C} 5$ & 5 & 4 & 5 & \\
\hline \multicolumn{2}{|c|}{ Profil Airlines Sempurna } & 4 & 3 & 4 & \\
\hline 1 & $\mathrm{C} 1$ & 1 & 2 & 1 & \multirow{5}{*}{ Gap } \\
\hline 2 & $\mathrm{C} 2$ & 0 & 0 & 0 & \\
\hline 3 & $\mathrm{C} 3$ & 0 & 1 & 0 & \\
\hline 4 & $\mathrm{C} 4$ & 1 & 1 & -1 & \\
\hline 5 & $\mathrm{C} 5$ & 1 & 1 & 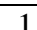 & \\
\hline
\end{tabular}


Keterangan : 1: Keutuhan barang, 2: Asuransi (kehilangan, kerusakan, tertukar),3: Keadaan fisik barang

\section{Menentukan Bobot}

Setelah diperoleh Gap pada masingmasing airlines, setiap airlines diberi bobot nilai sesuai ketentuan pada Tabel Bobot
Nilai Gap, mengacu pada tabel 3 bobot gap, maka diperoleh bobot Gap masing-masing kreteria sebagai berikut

Tabel 8. Hasil Pemetaan Gap Dan Hasil Bobot Nilai Gap Aspek Harga

\begin{tabular}{|c|c|c|c|c|c|c|c|}
\hline No & Sub Aspek & $\mathbf{1}$ & $\mathbf{2}$ & $\mathbf{3}$ & $\mathbf{4}$ & $\mathbf{5}$ & Keterangan \\
\hline 1 & $\mathrm{C} 1$ & -1 & 0 & 1 & 0 & 1 & Nilai Gap \\
\hline & $\mathrm{C} 1$ & 4 & 5 & 4,5 & 5 & 4,5 & Hasil Bobot Nilai \\
\hline
\end{tabular}

\begin{tabular}{|c|c|c|c|c|c|c|c|}
\hline No & Sub Aspek & 1 & 2 & 3 & 4 & 5 & Keterangan \\
\hline 2 & C2 & -1 & -1 & -1 & -2 & 0 & Nilai Gap \\
\hline & C2 & 4 & 4 & 4 & 3 & 5 & Hasil Bobot Nilai \\
\hline
\end{tabular}

\begin{tabular}{|c|c|c|c|c|c|c|c|}
\hline No & Sub Aspek & 1 & 2 & 3 & 4 & 5 & Keterangan \\
\hline 3 & C3 & -1 & -1 & -1 & -1 & 0 & Nilai Gap \\
\hline & C3 & 4 & 4 & 4 & 4 & 5 & Hasil Bobot Nilai \\
\hline
\end{tabular}

\begin{tabular}{|c|c|c|c|c|c|c|c|}
\hline No & Sub Aspek & 1 & 2 & 3 & 4 & 5 & Keterangan \\
\hline 4 & C4 & -1 & -2 & 0 & -1 & 0 & Nilai Gap \\
\hline & C4 & 4 & 3 & 5 & 4 & 5 & Hasil Bobot Nilai \\
\hline
\end{tabular}

\begin{tabular}{|c|c|c|c|c|c|c|c|}
\hline No & Sub Aspek & 1 & 2 & 3 & 4 & 5 & Keterangan \\
\hline 5 & C5 & -1 & -1 & 0 & -1 & 1 & Nilai Gap \\
\hline & C5 & 4 & 4 & 5 & 4 & 4,5 & Hasil Bobot Nilai \\
\hline
\end{tabular}

Dengan langkah-langkah yang sama akan dilakukan pada kreteria, waktu,kenyamanan, Keamanan

\section{Perhitungan dan pengelompokkan Core dan Secondary Faktor}

Setelah menentukan bobot nilai gap untuk ketiga aspek, yaitu aspek harga, waktu, kenyamanan, dan keamanan dengan cara yang sama, setiap aspek dikelompokkan menjadi 2 kelompok yaitu: "Core Faktor " dan "Secondary Faktor". Perhitungan core faktor dan secondary faktor untuk semua aspek dilakukan dengan terlebih dahulu menentukan subaspek mana yang menjadi core faktordan secondary faktor, misalnya core faktor dari aspek harga adalah sub aspek 1, 2, 4, dan 5, dan sub aspek sisanya akan menjadi secondary faktor.
Kemudian nilai core faktor dan secondary faktor tersebut dijumlahkan

Perhitungan CORE FAKTOR :

$$
\mathrm{NCF}=\frac{\sum \mathrm{NC}(\mathrm{h}, \mathrm{w}, \mathrm{ny}, \mathrm{a})}{\sum \mathrm{IC}}
$$

\section{Keterangan :}

NCF : Nilai rata-rata core faktor

$\mathrm{NC}$ (h,w,ny,a) : Jumlah total nilai core faktor ( harga, waktu, kenyamanan, keamanan )

IC : Jumlah item core faktor

Perhitungan SECONDARY FAKTOR :

$$
=N F S=\frac{\sum N S(\mathrm{~h}, \mathrm{w}, \mathrm{ny}, \mathrm{a})}{\sum I S}
$$


Keterangan :

NCF : Nilai rata-rata secondary faktor

NC ( h,w,ny,a) : Jumlah nilai total secondary faktor ( harga, waktu, kenyamanan, keamanan )
IS : Jumlah item secondary faktor

1. Aspek Harga

$\mathrm{NCF}=\frac{4+5+5+4,5}{4}=4,62$

$\mathrm{NSF}=4,5$

Tabel 9 Pengelompokan Bobot Nilai Gap Aspek Harga

\begin{tabular}{|l|l|l|l|l|l|l|l|l|}
\hline No & $\begin{array}{l}\text { Sub } \\
\text { Aspek }\end{array}$ & 1 & 2 & 3 & 4 & 5 & Core Faktor & $\begin{array}{l}\text { Secondary } \\
\text { Faktor }\end{array}$ \\
\hline 1 & C1 & 4 & 5 & 4.5 & 5 & 4.5 & 4.62 & 4.5 \\
\hline
\end{tabular}

Perhitungan core faktor dan secondary faktor pada tabel 9 dilakukan terlebih dahulu dengan menentukan subaspek mana yang menjadi core faktor.Sebagai contoh airlines dengan code C1 yang menjadi core faktor adalah subaspek 1, 2, 4, 5 dan secondary faktor adalah sub aspek 3. Dengan demikian nilai core faktor airlines dengan code $\mathrm{C} 1$ adalah 4, 5, 5, 4.5, keempat sub aspek tersebut akan dijumlah dan di bagi 4 (sesuai jumlah sub aspek yang menjadi core faktor), maka hasil yang diperoleh adalah 4,62 . Sedangkan yang menjadi secondary faktor adalah subaspek 3 dengan nilai 4,5. Langkah yang dilakukan untuk memperoleh nilai core faktor dan secondary faktor untuk kreteria waktu,kenyamanan, Keamanan.

\section{Perhitungan Nilai Total}

Dari perhitungan setiap aspek yang diatas, berikutnya dihitung nilai total berdasarkan presentase dari core faktor dansecondary faktor. Perhitungan aspek harga, aspek waktu, aspek kenyamanan dan aspek keamanan dengan nilai $60 \%$ dan $40 \%$ seperti berikut ini:

\section{$(x) \% . N C F(h, w, n y, a)+(x) \% . N S F(h, w, n y, a)=N(h, w, n y, a)$}

\section{Keterangan :}
$\mathrm{NCF}(\mathrm{h}, \mathrm{w}, \mathrm{ny}, \mathrm{a})$ : Nilai rata-rata core faktor (harga, waktu, kenyamanan, keamanan )
$\mathrm{NSF}(\mathrm{h}, \mathrm{w}, \mathrm{ny}, \mathrm{a})$ : Nilai rata-rata secondary faktor ( harga, waktu, kenyamanan, keamanan )
$\mathrm{N}(\mathrm{h}, \mathrm{w}, \mathrm{ny}, \mathrm{a}) \quad$ : Nilai total dari aspek

(harga, waktu, kenyamanan, keamanan )
(x)\%
: Nilai persen yang diinputkan ( harga, waktu, kenyamanan, keamanan )

Perhitungan Nilai Total untuk Aspek harga $\mathrm{Nh}=(60 \% \times 4,62)+(40 \% \times 4,5)=4,57$

Tabel 10. Nilai Total Aspek Harga

\begin{tabular}{|c|c|c|c|c|}
\hline No & Sub Aspek & Core Faktor & Secondary Faktor & Nh \\
\hline 1 & C1 & 4,62 & 4,5 & 4,57 \\
\hline
\end{tabular}

Dilihat dari perhitungan diatas nilai total aspek harga untuk airlines dengan code $\mathrm{C} 1$ yaitu nilai core faktor dikalikan $60 \%$ dan nilai dari secondary faktor dikalikan $40 \%$ maka diperoleh hasil nilai total sebesar 4,57. $\mathrm{Nh}=(60 \% \times 4)+(40 \% \times 4)=4$. Dengan 
cara yang sama akan dihitung sub kreteria C2,C3,C4 dan C5. Dan proses yang sama juga dilakukan untuk melakukan perhitungan pada kreteria Waktu, Kenyamanan dan Keamanan

\section{Perhitungan Penentuan Ranking}

Hasil akhir dari proses profile matching adalah ranking dari alternatif yang diajukan. Penentuan ranking mengacu pada hasil akhir perhitungan tertentu.

$$
\text { Ranking = (x)\%.Ni + (x)\%. Ns + (x)\%. Np + (x)\%. Nw }
$$

Keterangan :

Nh : Nilai Harga

Nw : Nilai Waktu

Nny : Nilai Kenyamanan

$\mathrm{Na}$ : Nilai Keamanan

(x)\% : Nilai Persen yang diinputkan
Hasil akhir $=(30 \% \times 4,57)+(30 \% \times 4,75)$

$+(15 \% \times 3,5)+(25 \% \times 4,1)$

$=1,37+1,42+0,52+1,02$

$=4,33$

Tabel 11. Hasil Nilai Perangkingan Dari Masing-masing Alternatif

\begin{tabular}{|c|l|c|}
\hline Ranking & \multicolumn{1}{|c|}{ Id / Nama Pesawat } & Hasil Akhir \\
\hline I & C2 ( Garuda Indonesia ) & 4,76 \\
\hline II & C5 ( Cathay Pasific ) & 4,47 \\
\hline III & C3 ( Emirates Airlines ) & 4,4 \\
\hline IV & C4 ( Thai Airlines ) & 4,34 \\
\hline V & C1 ( Korean Airlines ) & 4,33 \\
\hline
\end{tabular}

Dari data tabel 11, setiap alternatif dalam hal ini masing-masing airlines seperti pada dapat ditentukan nilai akhirnya yang akan menentukan posisi ranking. Hasil perhitungan dengan metode profil matching berdasarkan skor kriteria tertinggi, Merujuk pada tabel 11 hasil maka sistem merekomendasikan kepada customer untuk memilih pesawat $\mathrm{C} 2$ (Garuda Indonesia) sebagai pilihan. Berdasarkan hasil rekomendasi kemudian customer akan mengambil keputusan sendiri, sistem dalam hal ini memiliki kemampuan memberikan dukungan dalam pengambilan keputusan.

\section{SIMPULAN}

Berdasarkan pembahasan modeling kasus yang dilakukan hasil penelitian ini dapat disimpulkan bahwa modeling yang akan ditempelkan ke dalam sistem adalah
$60 \% \mathrm{NCF}(\mathrm{h}, \mathrm{w}, \mathrm{ny}, \mathrm{a})+(40 \% \mathrm{NSF}(\mathrm{h}, \mathrm{w}, \mathrm{ny}, \mathrm{a})=$ $\mathrm{N}(\mathrm{h}, \mathrm{w}, \mathrm{ny}, \mathrm{a})$, dan dari lima alternatif airlines dalam pemodelan yang direkomendasikan yang menduduki peringkat pertama dalam perankingan adalah airlines dengan code $\mathrm{C} 2$ yaitu Garuda Indonesia, yang memperoleh hasil akhir sebesar 4,76 . Hasil ini merupakan hasil dari perhitungan dengan metode profil matching berdasarkan empat kriteria aspek (harga, waktu, kenyamanan, dan keamanan). Selain itu hasil rancangan pemodelan dalam penelitian ini mampu mempermudah customer dalam melakukan pengambilan suatu keputusan dan dapat mempercepat proses peertimbangan pemilihan suatu alternatif airlines.

\section{KEPUSTAKAAN}

Anggreni, P. Y. (2013). Prosedur Penanganan Reservation di Sales 
Ticketing pada PT. Garuda Indonesia (Persero) Tbk Bagian Penerbangan Domestik di Bandara International Ngurah Rai Denpasar. Tugas Akhir. Administrasi Niaga. Politeknik Negeri Bali.

Ayatti, N. W. (2011). Administrasi Penitipan Barang Impor Foreign Airlines pada PT. Angkasa Citra Sarana Catering Service Denpasar. Tugas Akhir. Administrasi Niaga. Politeknik Negeri Bali .

Darmawan, D. (2013). Sistem Informasi Manajemen. Cetakan Pertama. Bandung: PT. Remaja Rosdakarya.

Kariati, N. M. (2012). Pemodelan Group Decision Support System Untuk Penentuan Penerima Beasiswa Tesis. Yogyakarta: Universitas Gadjah Mada.

Octaviana, N. (2013). Penerapan Sistem Kompensasi Karyawan di PT. Griya Pancaloka Nusa Dua. Tugas Akhir. Administrasi Niaga Politeknik Negeri Bali.

Sastriawan, P. I. (2011). Sistem Informasi Nilai Siswa di SMK Negeri 1 Kuta Selatan. Laporan Proyek Akhir. Teknik Elektro. Politeknik Negeri Bali.

Suryadi, kadarsah, dan Ramdani,M.Ali. 1998. Sistem Pendukung Keputusan Suatu Wacana Idealisasi Dan Implementasi Konsep Pengambilan Keputusan. PT. Remaja Rosdakarya: Bandung.

Wahyu Winarto, W. (2004). Sistem Informasi Manajemen Cetakan Pertama. Yogyakarta: UPP (Unit Penerbitan dan Percetakan).
Students Major Determination Decision Support Systems using Profile Matching Method with SMS Gateway Implementation ,https://media.neliti.com/media/publi cations/131441-ID-none.pdf di kunjungi pada tanggal 2 maret 2018

You Li ; Yuan Zhuang; Haiyu
Lan; Xiaoji Niu; Naser ElSheimy ; A Profile-Matching Method for Wireless Positioning, ieeexplore.ieee.org/document/7564 477/

https://industri.kontan.co.id/news/prospekbisnis-kargo-masih-cerah-di-2017; di kunjungi pada tanggal 2 maret 2018 